\title{
Correction to: A nudibranch removes rival sperm with a disposable spiny penis
}

\author{
Ayami Sekizawa $^{1,2} \cdot$ Shin G. Goto ${ }^{1}$ Yasuhiro Nakashima ${ }^{3}$
}

Published online: 20 December 2019

(c) The Author(s) 2019

\section{Correction to: Journal of Ethology (2019) 37:21-29 https://doi.org/10.1007/s10164-018-0562-z}

The article A nudibranch removes rival sperm with a disposable spiny penis, written by Ayami Sekizawa, Shin G. Goto and Yasuhiro Nakashima, was originally published Online First without Open Access. After publication in volume 37, issue 1, page 21-29 the author decided to opt for Open Choice and to make the article an Open Access publication. Therefore, the copyright of the article has been changed to (C) The Author(s) 2019 and the article is forthwith distributed under the terms of the Creative Commons Attribution 4.0 International License (http://creativecommons.org/licenses/ by/4.0/), which permits use, duplication, adaptation, distribution and reproduction in any medium or format, as long as you give appropriate credit to the original author(s) and the source, provide a link to the Creative Commons license, and indicate if changes were made.

The original article can be found online at https://doi.org/10.1007/ s10164-018-0562-z.

Ayami Sekizawa aym-ca15@hotmail.co.jp

1 Department of Biology and Geosciences, Graduate School of Science, Osaka City University, 3-3-138 Sugimoto Sumiyoshi-ku, Osaka, Osaka 558-8585, Japan

2 Present Address: Graduate School of Agricultural Science, Tohoku University, 468-1 Aramaki Aza Aoba, Aoba-ku, Sendai 980-0845, Japan

3 Nihon University, College of Economics, 3-2-1 Kanda-Misakicho, Chiyoda-ku, Tokyo 101-8360, Japan
The original article has been corrected.

Open Access This article is licensed under a Creative Commons Attribution 4.0 International License, which permits use, sharing, adaptation, distribution and reproduction in any medium or format, as long as you give appropriate credit to the original author(s) and the source, provide a link to the Creative Commons licence, and indicate if changes were made. The images or other third party material in this article are included in the article's Creative Commons licence, unless indicated otherwise in a credit line to the material. If material is not included in the article's Creative Commons licence and your intended use is not permitted by statutory regulation or exceeds the permitted use, you will need to obtain permission directly from the copyright holder. To view a copy of this licence, visit http://creativecommons.org/licenses/by/4.0/.

Publisher's Note Springer Nature remains neutral with regard to jurisdictional claims in published maps and institutional affiliations. 